\title{
The age of vines as a controlling factor of soil erosion processes in Mediterranean vineyards
}

\author{
Jesús Rodrigo-Comino ${ }^{\mathrm{a}, \mathrm{b}, *}$, Eric C. Brevik ${ }^{\mathrm{c}}$, Artemi Cerdà ${ }^{\mathrm{d}}$ \\ a Instituto de Geomorfología y Suelos, Department of Geograpy, University of Málaga, 29071 Málaga, Spain \\ b Physical Geography, Trier University, 54286 Trier, Germany \\ c Department of Natural Sciences, 291 Campus Drive, Dickinson State University, Dickinson, ND 58601, USA \\ d Soil Erosion and Degradation Research Group, Department of Geography, University of Valencia, 46010, Valencia, Spain
}

\section{H I G H L I G H T S}

- The age of a vineyard's plantation was found to be a controlling factor in soil erosion.

- ISUM surveyed the soil topography in rows and inter-rows rapidly and at low-cost.

- A 2-year old vineyard plantation registered soil erosion rates of $-8.16 \mathrm{Mg} \mathrm{ha}^{-1}$ $\mathrm{yr}^{-1}$.

- In a 25-year old vineyard plantation soil erosion rates were $-1.61 \mathrm{Mg} \mathrm{ha}^{-1} \mathrm{yr}^{-1}$.

- Soil conservation measures should be applied following plantation

\section{A R T I C L E I N F O}

\section{Article history:}

Received 17 July 2017

Received in revised form 19 October 2017

Accepted 20 October 2017

Available online 24 October 2017

\section{Keywords:}

Vineyard

Age of plantation

Soil erosion

ISUM
G R A P H I C A L A B S T R A C T

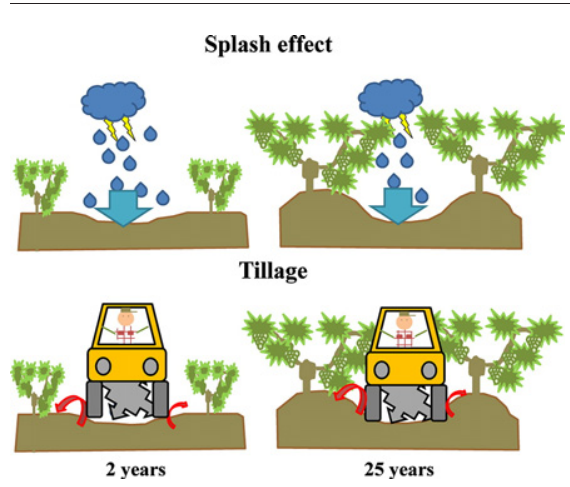

\section{A B S T R A C T}

Vineyards incur the highest soil and water losses among all Mediterranean agricultural fields. The state-of-the-art shows that soil erosion in vineyards has been primarily surveyed with topographical methods, soil erosion plots and rainfall simulations, but these techniques do not typically assess temporal changes in soil erosion. When vines are planted they are about $30 \mathrm{~cm}$ high $\times 1 \mathrm{~cm}$ diameter without leaves, the root system varies from 2 to over $40 \mathrm{~cm}$ depth, and sometimes the lack of care used during transplanting can result in a field with highly erodible bare soils. This means that the time since vine plantation plays a key role in soil erosion rates, but very little attention has been paid to this by the scientific community. Thus, the main goal of this research was to estimate soil losses and assess soil erosion processes in two paired vineyard plantations of different ages. To achieve this goal, the improved stock unearthing method (ISUM) was applied to vineyards on colluvial parent materials with similar soil properties, topographical characteristics and land managements in the Les Alcusses Valley, southwestern Valencia province, Spain. Our findings suggested that the old vineyards showed lower erosion rates $\left(-1.61 \mathrm{Mg} \mathrm{ha}^{-1} \mathrm{yr}^{-1}\right)$ than those that were recently planted $\left(-8.16 \mathrm{Mg} \mathrm{ha}^{-1} \mathrm{yr}^{-1}\right)$. This is because of the damage that the plantation of the vines causes to soil. Tillage after planting ( 4 times per year) resulted in changes in the inter-row and row morphology, promoting the development of a ridge underneath the vines that disconnected the inter-rows and reduced soil losses with time. After the second year and until the 25 th year after plantation, soil erosion was approximately $1 \mathrm{Mg} \mathrm{ha}^{-1} \mathrm{y}^{-1}$, which means that most of the erosion took place during the first two years after the plantation. Soil conservation strategies should be applied immediately after the plantation works to allow sustainable grape production. That is when soil erosion most needs to be controlled.

(c) 2017 Elsevier B.V. All rights reserved.

\footnotetext{
* Corresponding author

E-mail addresses: rodrigo-comino@uma.es (J. Rodrigo-Comino), eric.brevik@dickinsonstate.edu (E.C. Brevik), artemio.cerda@uv.es (A. Cerdà).
} 


\section{Introduction}

Agricultural lands are one of the most important sources of sediments and runoff in the world's watersheds (García-Ruiz et al., 2017; Kimoto et al., 2006; Le Gall et al., 2017). This is because of management that often leaves bare soils, such as intensive tillage and use of herbicides, and creates soil compaction by heavy machinery (Brevik and Fenton, 2004; Keesstra et al., 2016a). Non-sustainable soil erosion rates have consistently been reported in orchards and vineyards. Olive (Taguas et al., 2013, 2015), persimmon (Cerdà et al., 2016), citrus (Cerdà et al., 2017a; Jianjun et al., 2017), apricots (Keesstra et al., 2016b) and avocado (Atucha et al., 2013) plantations have been found to deliver more sediment and water than nearby natural areas. Vineyards yield the highest soil and water losses (Biddoccu et al., 2016; Napoli et al., 2016; Novara et al., 2013; Prosdocimi et al., 2016a; Rodrigo-Comino et al., 2016a). This is due to the lack of leaf cover during the winter and low plant cover in summer that allows raindrops access to the soil surface and the intensive use of tillage (Lasanta, 1985; Rodrigo-Comino et al., 2017a).

Therefore, the high erosion rates in vineyards and orchards are well known. We also know the factors that enhance them such as bare soils (Morvan et al., 2014; Napoli et al., 2017b), sloping terrain (RodrigoComino et al., 2017a), extreme rainfall events (Martínez-Casasnovas et al., 2002; Ramos and Martínez-Casasnovas, 2009), intense tillage (Arnaez et al., 2007; Bogunovic et al., 2017; Napoli et al., 2017a) and the abuse of herbicides (García-Díaz et al., 2017; Salome et al., 2014). However, although rates of soil losses from individual rainfall events or over an average year have been investigated, and the factors of erosion in vineyards have been studied by the scientific community, there is little information about the temporal evolution of soil erosion rates and long-term soil erosion rate studies are rare. Little attention has been paid to previous tillage practices, land levelling and terracing actions carried out during the plantation time and to the age of the plants (Biddoccu et al., 2013). Prior to vine planting, the soil is levelled and, commonly in Mediterranean areas, terraced to maintain a flat surface (Ramos and Porta, 1997; Tarolli et al., 2015). Then, the young vines are planted by hand or machinery but do not have a leaf cover or developed root system to protect the soil from high erosion rates (Reubens et al., 2007). This means the soil remains exposed and very erodible after the plantation works as the small vine stocks $(30 \mathrm{~cm}$ high $\times 1 \mathrm{~cm}$ diameter) with $3-5 \mathrm{~cm}$ of roots cover $<1 \%$ of the soil surface. As the vines grow, they provide a higher level of soil cover and a more developed root system to hold soil in place. However, in a nutshell, while the time since plantation plays a key role in soil erosion rates, very little attention has been paid to this topic. Recent research has demonstrated that soil erosion rates in vineyards were higher during the years immediately after the plantation and that erosion decreased when the vines matured (Cerdà et al., 2017a; Rodrigo-Comino et al., 2017b). These studies were carried out with open plots and rainfall simulations that researched soil erosion by water, but in vineyards soil erosion is the result of a combination of water and tillage erosion.

To determine the effect of age since plantation on soil erosion a method is needed that will provide information about long-term soil erosion rates. This method should also inform about landform changes in the vineyards as landform evolution is important in erosion rate evolution and sheds light on changes in the spatial redistribution of the material that is transported. To achieve this goal, we selected a microtopographical method that is based on the height of the graft union, called the Stock Unearthing Method (SUM). This method has been found to be accurate enough to document soil erosion in vineyards (Brenot et al., 2008; Casalí et al., 2009; Paroissien et al., 2010). However, there are opportunities to improve SUM. Its main weakness is the assumption that the inter-row is flat, without considering uncertainties generated by rills, footprints, and tractor passes (Brenot et al., 2008). Therefore, an update to the method that provides a proper spatial assessment of the landforms and, then, of the sinks and sources of sediments would be a meaningful improvement.

The main goal of this research was to estimate soil losses and to assess soil erosion processes in two paired vineyard plantations that were two different ages. To achieve this goal, an improved stock unearthing method (ISUM) was applied on colluvial parent materials in vineyards near Valencia, Spain. The ISUM measured three more points in the inter-row space in addition to the original measurement points on the vine graft union used by SUM. This may be relevant to determining long-term soil erosion rates and developing soil erosion conservation practices.

\section{Material and methods}

\subsection{Study area and soil descriptions}

The study site is located in the Les Alcusses Valley (Moixent municipality), within the traditional viticulture region of the Terres dels Alforins in Valencia (Fig. 1). The parent material belongs to a lithological facies of colluviums from limestones, sandstones and dolomitic materials deposited along the footslope, where the vines were planted. The climatic characteristics are typically Mediterranean, characterized by 3 to 5 months of drought during the summer. The mean total annual rainfall is about $350 \mathrm{~mm} \mathrm{yr}^{-1}$ and average annual temperature is $13.8^{\circ} \mathrm{C}$. The climate type can be classified as BSk (Köpppen and Geiger, 1954; Peel et al., 2007).

The study site was comprised of two paired-vineyards that were planted to a Monastrell grape variety and belong to Pablo Calatayud (Celler del Roure winery). They were planted at different times but with similar management and arrangement within the vine training system. The young plot vineyard was planted two years prior to the study and the older one 25 years prior to the study, both on an inclination from 5 to $10 \%$. In the 2-year old vineyard, the plantation framework was $3.0 \times 0.75 \mathrm{~m}(>160$ vines per row $)$ while it was $3.0 \times 1.4 \mathrm{~m}(\approx 130$ vines per row) in the 25 -year old vineyard. Both vineyards were planted parallel to the contour lines (perpendicular to the rows).

Before the plantation, soil was levelled and the vines were planted into a flat and smooth terrain. Four different tractor passes were performed each year to till the soil. Two soil profiles were described in order to put the main physical and chemical characteristics in context (an example of the soil pit in the 25-year old vineyard is shown in Fig. 2). Soil profiles in both vineyards were characterized by diffuse boundaries and fine and very widely spaced surface cracks. High gravel content with clasts that were angular to sub-rounded and slightly weathered was noted within the five first centimetres $(\approx 10 \%)$. The soil structure was between moderate and strong, with medium blocky aggregates. The consistency was soft, non-sticky and between slightly plastic and plastic under wet conditions. Compaction signals were clear, dominating the soil profile down to $15 \mathrm{~cm}$ particularly in weakly and moderately cemented sections. In the inter-row areas only very few fine roots were found. On the contrary, in the row areas, the root system was more developed, showing greater biological activity. The predominant colour in dry soils was 10 YR 4-6. After wetting the soil, two different colours were observed: at the beginning 7.5 YR 4-6 and at the end 10 YR 3-6. Soil carbonate content was about $45 \%$ and $\mathrm{pH}_{\mathrm{H} 2 \mathrm{O}} 8.2$. The soil texture was clay loam characterized by $43 \%$ sand, $20 \%$ silt and $37 \%$ clays. Finally, due to the intense tillage and conventional management, the soil profiles were classified as Terric Anthrosols with colluvic materials (IUSS Working Group WRB, 2014).

\subsection{Improved stock unearthing method (ISUM), soil erosion estimation and soil level mapping}

The vine graft union has an unearthing or buried signal, which an expert eye can use to distinguish the distance between the vine stock and the soil level when measurements are taken. Brenot et al. (2008) and 


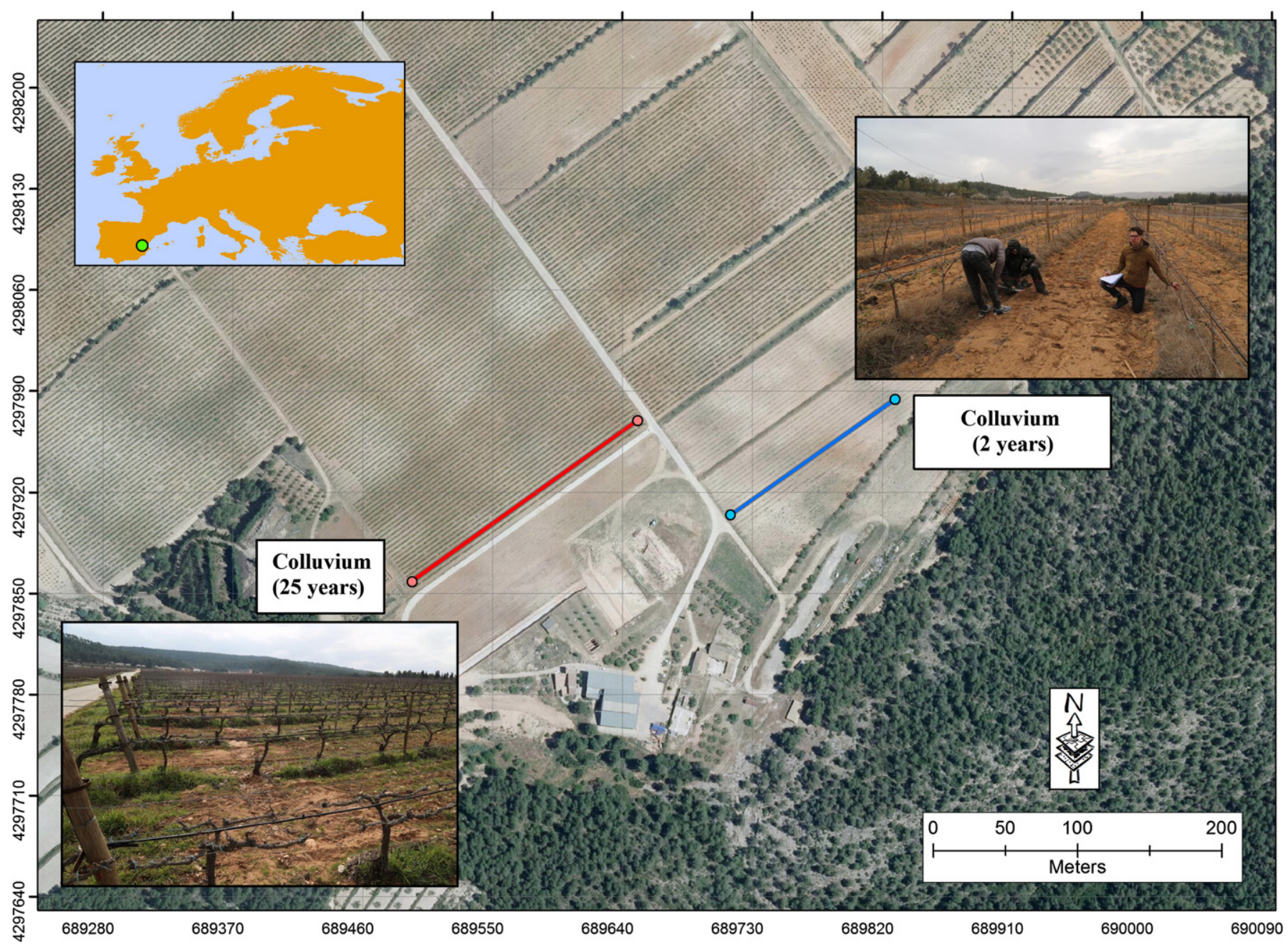

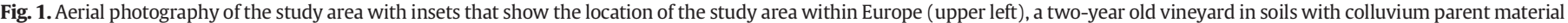
(upper right), and a 25-year old vineyard in soils with colluvium parent materials (lower left).

Casalí et al. (2009) used the distance of the graft union above or below the original soil level as a permanent botanical benchmark, because this point remains constant without growing vertically. Only the new part of the vine that corresponds to the new grape variety that was grafted to the root stock will grow from this initial point (Rodrigo-Comino et al., 2016b). When manually planting, the graft union is consistently placed $2 \mathrm{~cm}$ above the initial soil surface to allow the vine to avoid complications caused by soil moisture, freezing, and fungal pests. This was confirmed by the vine growers and in a parallel control plot planted few months prior to the study.

The traditional stock unearthing method (SUM) measures the distance between the frontal mark on the graft union and the soil surface (Brenot et al., 2006, 2008). However, the assumption that the soil surface in the inter-row areas remains planar, without effects from the increased roughness effect of rills, footpaths, and wheel tracks introduces errors into the final estimations. Previous investigations (Biddoccu et al., 2017; Paroissien et al., 2010; Rodrigo-Comino et al., 2015) found that: i) soil is constantly reallocated due to the passing of machinery; ii) the surface is washed by splash and overland flow; and, iii) materials can be consolidated or become less dense depending on the temperature, soil moisture and the soil matrix after tillage.

Thus, we felt that SUM should be improved by including three measurements (points) across the inter-row area. Therefore, for the four measured rows ( 2 in the 2 -year old vineyard and 2 in the 25 -year old one), we first identified the paired-vine graft stock unions and found the point along the vine stock precisely $30 \mathrm{~cm}$ above the union graft to enable recording each extra point, either buried or above the soil surface. Second, we stretched a meter tape between these elevated points on the graft unions, and with a meter stick we measured the distance from the stretched meter tape to the soil level at three different distances ( $1 \mathrm{~m}$ from the left vine, in the middle at $1.5 \mathrm{~m}$ and $1 \mathrm{~m}$ from the right vine) from the reference vine stalk. Positive measurements (buried) corresponded to areas where sedimentation had occurred and negative measurements corresponded to areas where erosion had occurred.

The entire data set was transformed into vectorial format with ArcGis 10.5 (ESRI) and incorporated as a point net. From these five points for every paired-vine we generated two comparable DEMs (digital elevation models) in raster file format by using the tool "Topo-toraster". Topo-to-raster is "a discretized thin plate spline technique" (Wahba, 1990) for which the roughness penalty has been modified to allow the fitted DEM to follow abrupt changes in terrain, such as streams, ridges and cliffs (http://desktop.arcgis.com/en/arcmap/10.3/ tools/3d-analyst-toolbox/topo-to-raster.htm) These two raster files had a higher accuracy (cell size: $0.5 \mathrm{~m}$ ) and precision than traditional mapping methods that allowed the development of final maps to estimate soil erosion rates. The final maps also allowed the representation of linear erosion features in the inter-row areas (e.g. rills, accumulations or mass transports).

In total, we measured $600(173 \times 2$ in 2-years old vines $+127 \times 2$ in 25 -years old vines) graft unions (Vine 1 - left side- and Vine 2 right side-), from the end part of the graft union to the soil level. Including 

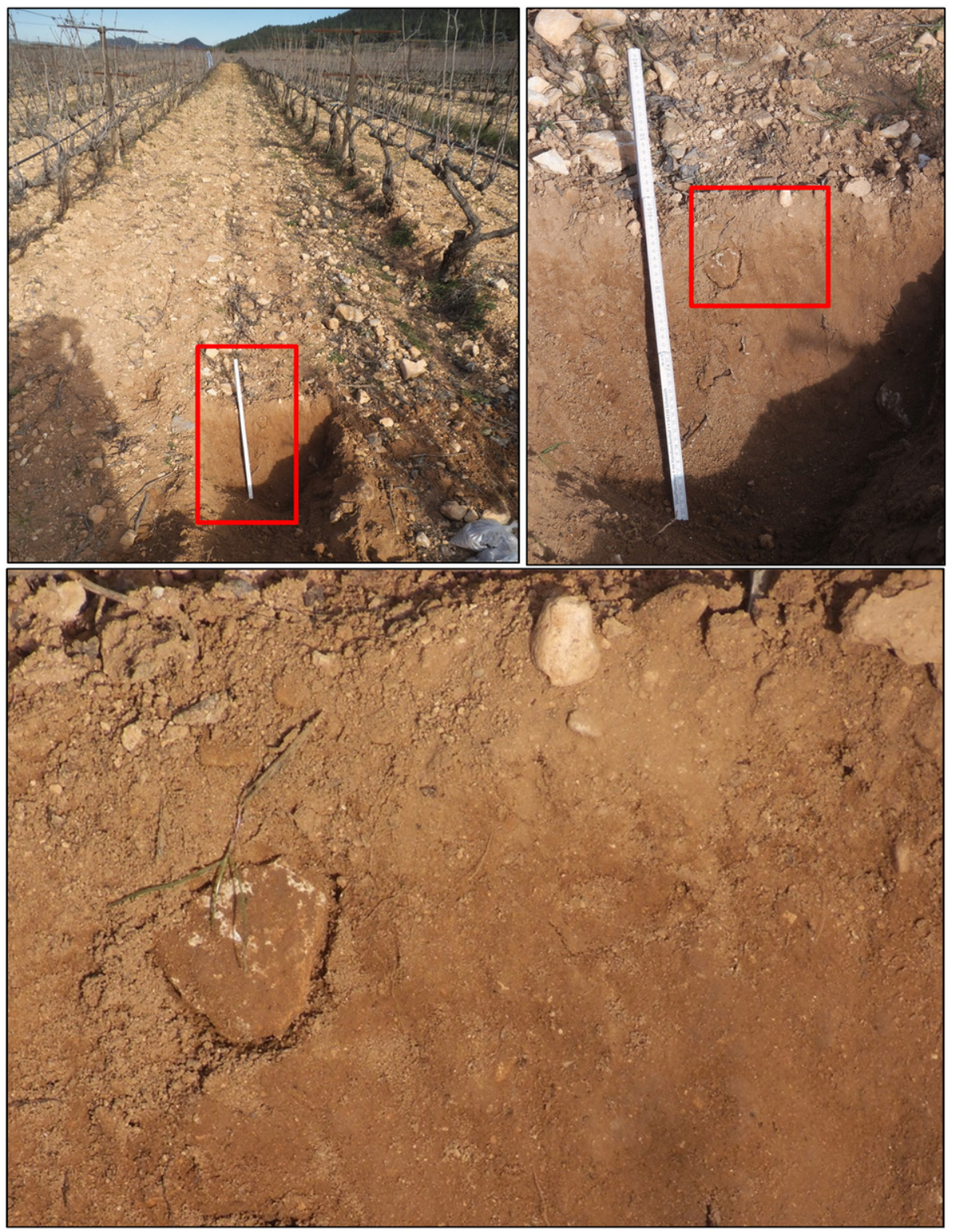

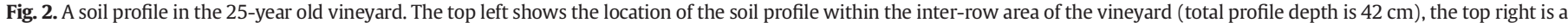
zoomed-in view of the entire soil profile, and the bottom shows a detailed view of part of the upper portion $(28-42 \mathrm{~cm})$ of the soil profile.

the inter-row area measurements, 865 and 635 points were measured in the 2-year old and 25-year old vineyards, respectively. The same researcher took all measurements throughout the study. If the high soil roughness under a vine generated small steps or exposed stones or vegetation cover altered the visibility of the graft union, the impediment was carefully eliminated. For the final quantification, an addition of $2 \mathrm{~cm}$ was used for all the points, corresponding to the initial graft union elevation.

\subsection{Statistical analysis and soil erosion estimations}

Total averages and maximum and minimum values from ISUM in the 2-year old and 25-year old vineyards were calculated and presented in the form of tables and scatter plots. Next, to compare the results obtained from each paired-vine, a one-way ANOVA test was carried out. However, Shapiro-Wilk and equal variance tests indicated the data were not normally distributed. Therefore, a Mann-Whitney $U$ test was performed where significant differences at $p<0.001$ level were obtained.
The total volume of soil loss $\left(\mathrm{m}^{3}\right)$ was estimated as the volume difference between the soil level at the time of the measurements $\left(t_{1}\right)$ and the initial soil surface topography $\left(t_{0}\right)$ estimated from the ISUM measurements. In fact, since the analysis is on the entire plot, the required volume $\left(\mathrm{m}^{3}\right)$ was calculated by multiplying the plot surface $\left(\mathrm{m}^{2}\right)$ by the average of the measured distances $(\mathrm{cm})$ between the botanic marks on the graft union and the actual visible rootstock. Average annual soil loss (ER: $\mathrm{Mg} \mathrm{ha}^{-1} \mathrm{yr}^{-1}$ ) was estimated from the erosion-deposition equation (eq. 1) proposed by Paroissien et al. (2010):

$\mathrm{ER}=\frac{\mathrm{Vol} \times \mathrm{Bd}}{\mathrm{St} \times A v} \frac{\mathrm{Vol} \times \mathrm{Ds}}{S t \times A}$

where $\mathrm{Vol}\left(\mathrm{m}^{3}\right)$ is the volume occupied by the depleted (eroded) or accumulated soil, St (ha) is the total area for the considered field unit, $A v$ (yr) is the age of the vines and $B d$ is the soil bulk density $\left(\mathrm{g} \mathrm{cm}^{-3}\right)$. Reference values for soil bulk density were mean soil bulk density measured from the 7 soil samples collected in a steel cylinder after performing the measurements at different positions along the inter- 
row. $B d$ was $1.05 \mathrm{~g} \mathrm{~cm}^{-3}$ for the 2-year-old vineyard and $1.23 \mathrm{~g} \mathrm{~cm}^{-3}$ for the 25-year old vineyard. We should note that there are significant changes in bulk density in the first years after initial planting of vines that may also change the surface height independently of erosion.

\section{Results}

\subsection{ISUM measurements in row and inter-row areas}

Two scatter plot graphics with the total average measured points of the 2-year old and 25-year old vineyards in the row and inter-row areas are included in Fig. 3. Descriptive statistics (total averages, median, maximum and minimum values) can also be observed in Table 1 . In the 2-year old vineyard the average measurements had negative values, showing the predominance of soil depletion (Fig. 3, 2-year old vineyard). The highest detachment amounts were recorded in the interrow measurements, ranging from $-4.53 \pm 3.27 \mathrm{~cm}(1.5 \mathrm{~m}$ from the vine stock row 1 ) to $-5.23 \pm 3.29 \mathrm{~cm}$ ( $1 \mathrm{~m}$ from the vine stock row 2). Soil accumulation was noted in vine stocks from $+0.43 \pm 3.85 \mathrm{~cm}$ to $+1.04 \pm 4.34 \mathrm{~cm}$. In the row areas, the maximum positive value was $+16 \mathrm{~cm}$, while $+11 \mathrm{~cm}$ was the maximum in the inter-row. The minimum values recorded were $-17 \mathrm{~cm}$ and $-9 \mathrm{~cm}$ in the inter-row and row areas, respectively. The highest average detachment was observed in the last two sections (from 140 to $>160$ vines), where sinks and prolonged linear erosion features were found (Fig. 4). Under vine stocks, soil accumulation was the predominant feature.

In the 25-year old vineyard, the negative and positive value measurements were relatively similar (Fig. 3, 25-year old vineyard). The highest detachment was found in the middle part of the inter-row area, reaching $-4.4 \pm 3.27 \mathrm{~cm}$. The other two inter-row measurements also had negative average values. In the row area, values were highly different. At vine 1, positive values were recorded $(+6.91 \pm 3.85 \mathrm{~cm})$. On the contrary, at the opposite vine (2) no-changes from the initial condition were observed $(-0.28 \pm 4.34 \mathrm{~cm})$. This is due to tillage and splash effect transport of sediments in the lower row position. Maximum accumulation values reached higher values in the row areas $(+21 \mathrm{~cm})$ and lower values in the inter-row areas $(+2 \mathrm{~cm})$. On the contrary, the highest minimum values were from -14 to $-15 \mathrm{~cm}$ in the row areas, and from -9 to $-12 \mathrm{~cm}$ in the inter-row areas. The most relevant linear erosional features and sinks were noted from sectors $60-80$ to $100-120$ (Fig. 5), which are connected with the above row. Statistical analysis (Table 2) showed that in all comparisons performed between rows and inter-rows total average values with significant differences $(p<0.001)$ were obtained.

\subsection{Soil detachment and accumulation estimations using ISUM}

Estimations of soil erosion rates were calculated applying ISUM to row and inter-row areas (Table 3 ). Results demonstrated that several differences existed between row and inter-row areas, and between 2year old and 25-year old vineyards. In the 2-year old vineyard, total soil depletion of $-8.16 \mathrm{Mg} \mathrm{ha}^{-1} \mathrm{yr}^{-1}$ was found. In the rows, an accumulation of $+1.27 \mathrm{Mg} \mathrm{ha}^{-1} \mathrm{yr}^{-1}$ was found with a soil detachment of $-9.43 \mathrm{Mg} \mathrm{h}^{-1} \mathrm{a} \mathrm{yr}^{-1}$ in the inter-rows. In the 25-year old vineyard, total soil erosion (1.61 $\mathrm{Mg} \mathrm{ha}^{-1} \mathrm{yr}^{-1}$ ) was much lower than in the 2year old vineyard. In the rows, $+6.04 \mathrm{Mg} \mathrm{ha}^{-1} \mathrm{yr}^{-1}$ were found and in the inter-rows $-7.65 \mathrm{Mg} \mathrm{ha}^{-1} \mathrm{yr}^{-1}$. The 25 -year old vineyard soil erosion rate showed the average over the entire 25 years, but the information allowed estimation of soil erosion from years 3 through 25 for the 2-year old vineyard. This calculation predicts that soil erosion rates will be much lower, $-1.04 \mathrm{Mg} \mathrm{ha}^{-1} \mathrm{yr}^{-1}$, after the impacts disturbing the soil during the plantation, when are minimized.

\section{Discussion}

The driving factors of soil erosion are high slope angles, lack of vegetation, weak soil aggregate stability and extreme rainfall events (Martinez-Casasnovas et al., 2002; Richter, 1979). However, vineyard
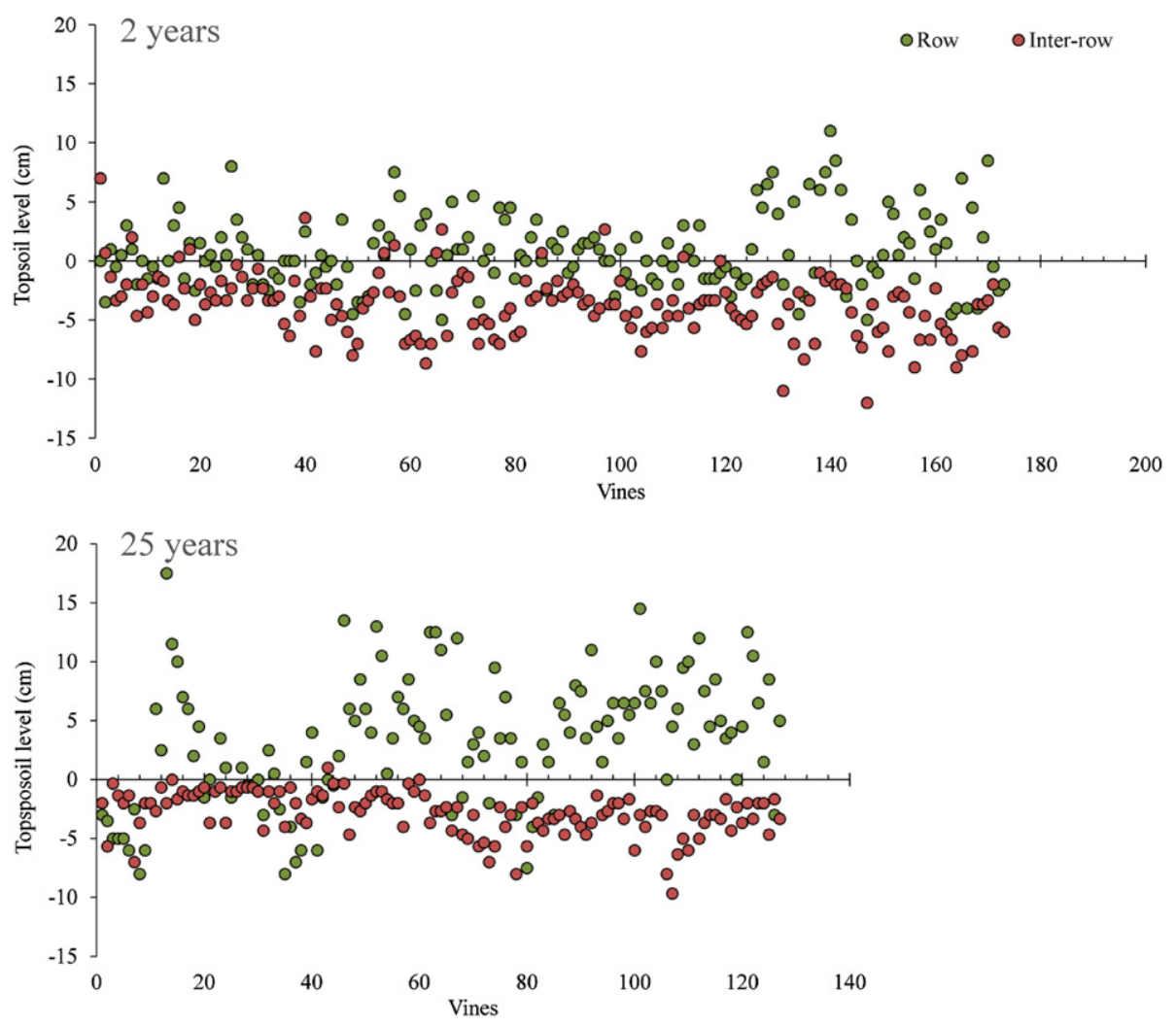

Fig. 3. Scatter plot with the total average measures for row and inter-row areas of the 2- and 25-year old vineyards. 
Table 1

Total averages $(\bar{x})$, maximum (max) and minimum ( $\mathrm{min}$ ) of distance from the graft union to the soil level in 2- and 25-year old vineyards.

\begin{tabular}{|c|c|c|c|c|c|c|c|c|}
\hline & Years & Vine 1 & $1 \mathrm{~m}$ & $1.5 \mathrm{~m}$ & $1 \mathrm{~m}$ & Vine 2 & $\operatorname{Row}(\bar{x})$ & Inter-row $(\bar{x})$ \\
\hline $\bar{x} \pm(\mathrm{cm})$ & $\begin{array}{l}2 \\
25\end{array}$ & $\begin{array}{l}+0.43 \pm 3.85 \\
+6.91 \pm 3.85\end{array}$ & $\begin{array}{l}-1.58 \pm 3.3 \\
-1.02 \pm 6.61\end{array}$ & $\begin{array}{l}-4.53 \pm 3.27 \\
-4.4 \pm 3.27\end{array}$ & $\begin{array}{l}-5.23 \pm 3.29 \\
-2.98 \pm 3.29\end{array}$ & $\begin{array}{l}+1.04 \pm 4.34 \\
-0.28 \pm 4.34\end{array}$ & $\begin{array}{l}+0.73 \pm 3.11 \\
+3.31 \pm 3.11\end{array}$ & $\begin{array}{l}-3.78 \pm 2.8 \\
-2.8 \pm 3.48\end{array}$ \\
\hline $\operatorname{Max}(\mathrm{cm})$ & $\begin{array}{l}2 \\
25\end{array}$ & $\begin{array}{l}+10 \\
+21\end{array}$ & $\begin{array}{l}+11 \\
+2\end{array}$ & $\begin{array}{l}+7 \\
+1\end{array}$ & $\begin{array}{l}+6 \\
+1\end{array}$ & $\begin{array}{l}+16 \\
+15\end{array}$ & & \\
\hline $\operatorname{Min}(\mathrm{cm})$ & $\begin{array}{l}2 \\
25\end{array}$ & $\begin{array}{l}-9 \\
-15\end{array}$ & $\begin{array}{l}-16 \\
-9\end{array}$ & $\begin{array}{l}-16 \\
-12\end{array}$ & $\begin{array}{l}-17 \\
-11\end{array}$ & $\begin{array}{l}-13 \\
-14\end{array}$ & & \\
\hline
\end{tabular}

Vine 1: Vine in the left side; Vine 2: Vine in the right side. $1 \mathrm{~m}, 1.5 \mathrm{~m}$ and $1 \mathrm{~m}$ represent the point measured in the inter-row areas taken from the Vine 1 and Vine 2.

soils are greatly altered by intensive tillage, non-sustainable land management using chemicals that increase soil contamination and erosion, and nutrient impoverishment due to the lack of organic fertilization (García-Díaz et al., 2017; Novara et al., 2011; Serpa et al., 2017). Therefore, vineyards are areas of high erosion rates. The age of vineyards as a key factor controlling soil erosion processes has received minimal attention and interest from the scientific community. A clear example of relevance of the time since plantation as a driving factor in soil erosion may be seen in the investigations carried out in conventional sloping vineyards in the Ruwer-Mosel Valley of Germany. By using rainfall simulations, Rodrigo-Comino et al. (2017b) demonstrated that young vineyards had higher soil losses $\left(53.3 \mathrm{~g} \mathrm{~m}^{-2}\right)$ and runoff $\left(7.7 \mathrm{~L} \mathrm{~m}^{-2}\right)$ than older ones $\left(29.7 \mathrm{~g} \mathrm{~m}^{-2}\right.$ and $5.2 \mathrm{~L} \mathrm{~m}^{-2}$ ). In the same region, (Rodrigo-Comino et al., 2017b) used Gerlach troughs in open plots to show that the highest overland flow and soil losses were registered during the first year after plantation with drastic decreases in both over the next two years. Other studies that support the hypothesis that vineyard age is important in determining soil erosion rates have used the RUSLE (Revised Universal Soil Loss Equation), rainfall simulations and the Stock Unearthing Method (SUM) (Rodrigo-Comino et al., 2015, 2016a, 2016b).

The results show that soil erosion in vineyards occurs due to the combined processes of tillage and surface wash (Fig. 6). Tillage plays a key role in redistributing soil materials and forming new topography that affects final erosion rates (Wang et al., 2017). Tillage can be considered as driving factor of soil erosion, but its impact on soil roughness and connectivity of flows has not been investigated. The effect of tillage changes the soil's topography, and the topographical measurements

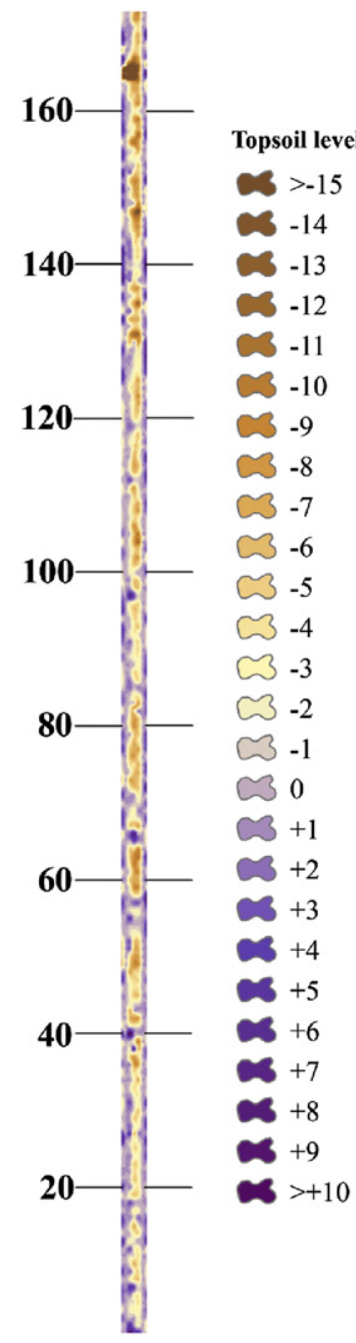

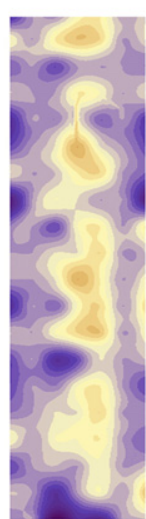
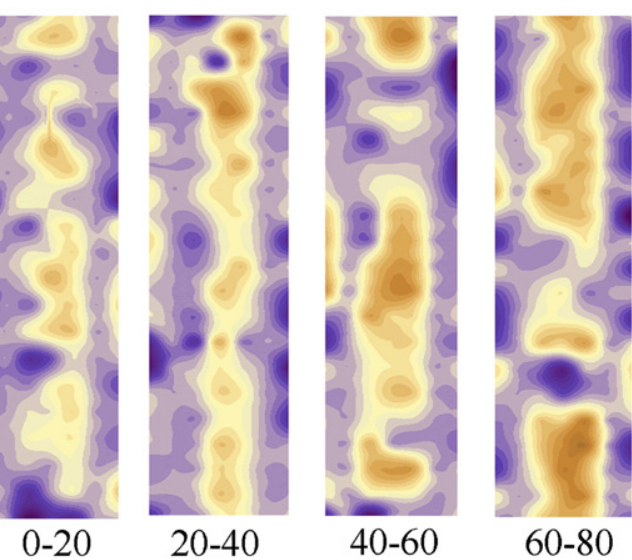

$60-80$
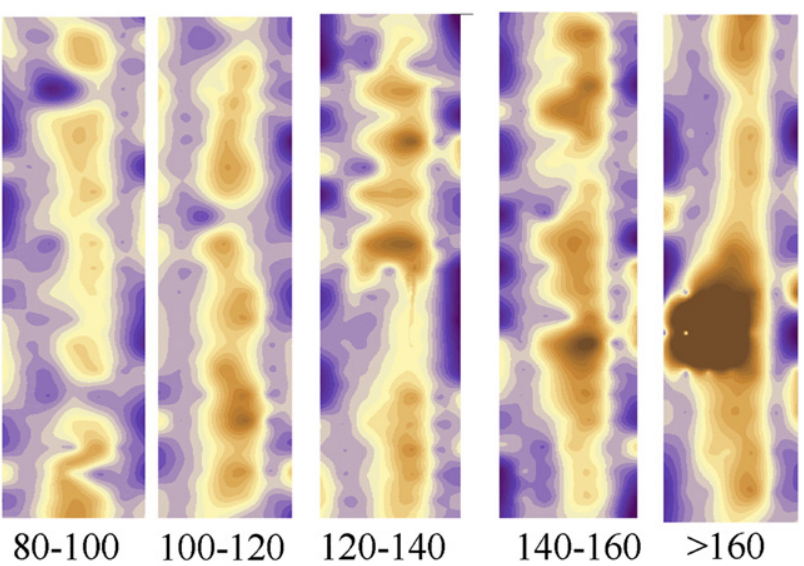

Fig. 4. ISUM map of 2-year old vineyard. Each number means the number sections of vines planted in the inter-row. 


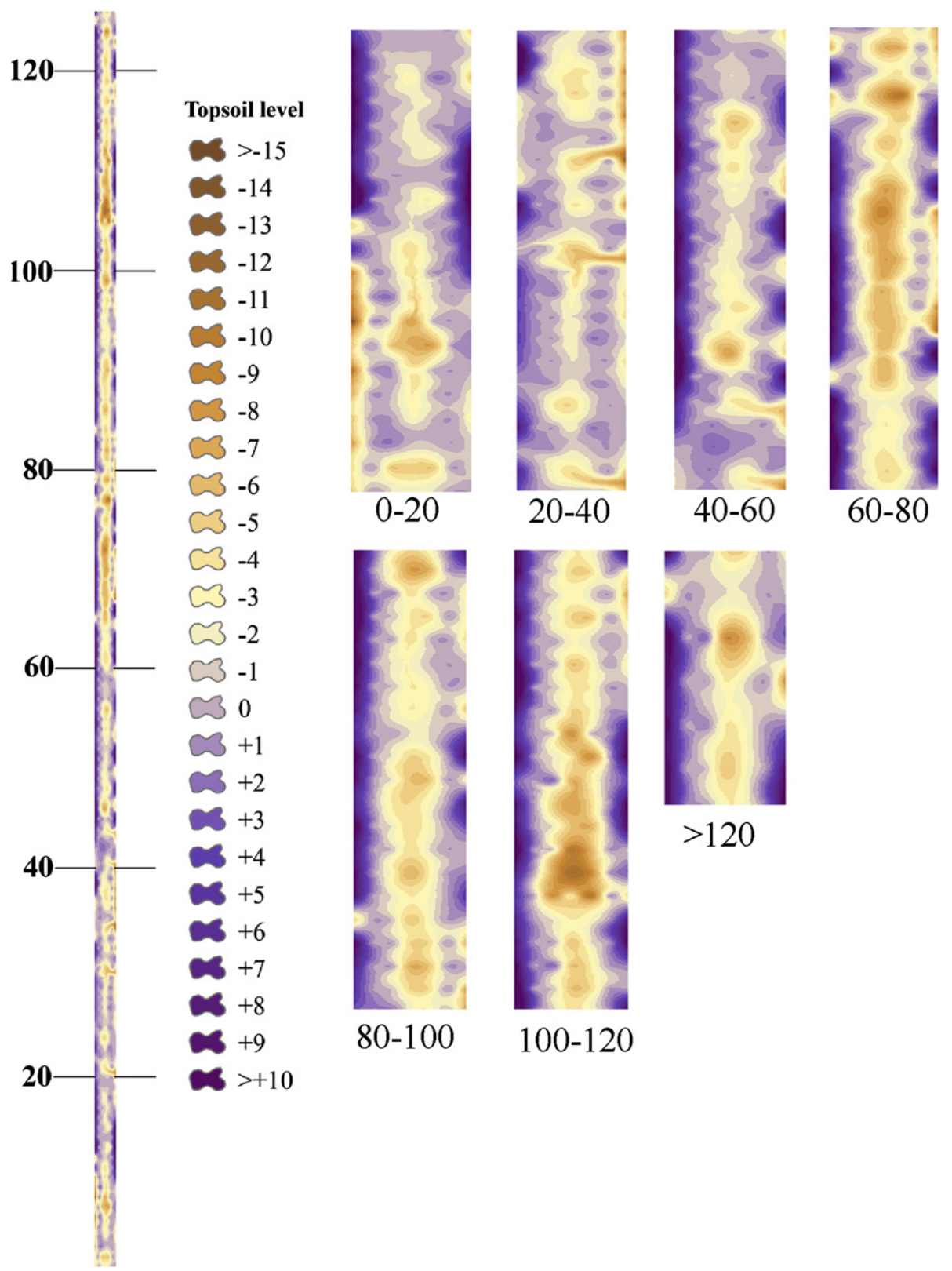

Fig. 5. ISUM map of 25-year old vineyard. Each number means the number sections of vines planted in the inter-row.

carried out by the ISUM methods survey this change with precision and allow it to be monitored. This can then shed light on the connectivity of overland flow and the final soil erosion rates. This will allow us to understand the connectivity of flows such as Masselink et al. (2017a) found in agriculture catchments using rare-earth oxide traces within a network theory approach to allow a better understanding of overland flow connectivity (Masselink et al., 2017b) (Fig. 7).

Tillage has been shown to be a key factor in soil redistribution in agricultural land (Govers et al., 1996). Farmers try to create a flat, smooth

Table 2

All paired-multiple comparisons between young and old vineyards *Y: Young (2-years); O: Old (25-years). Normality test (Shapiro-Wilk).

\begin{tabular}{lll}
\hline & $p$ & Diff. \\
\hline Y: Row vs Inter-row & $<0.001$ & Yes \\
O: Row vs Inter-row & $<0.001$ & Yes \\
Row (O) vs Row (Y) & $<0.001$ & Yes \\
Inter-row (O) vs Inter-row (Y) & $<0.001$ & Yes \\
Averages O vs Y & $<0.001$ & Yes
\end{tabular}

and low roughness soil surface in vineyards during plantation (Cerdà et al., 2017b). However, after 2 years tillage redistribution results in an increase in roughness with some material already located under the rows. This morphology of ridges under the vines and concave depressions in the center of the row is well established after 25 years. The

Table 3

Soil loss and accumulation estimations for 2- and 25-year old vineyards.

\begin{tabular}{lllll}
\hline Vineyards & Value & ISUM & Row & Inter-row \\
\hline 2-Years old & $\mathrm{m}^{3}$ & -5.54 & +0.86 & -6.41 \\
& $\mathrm{Mg} \mathrm{ha}^{-1}$ & -5.82 & +0.91 & -6.73 \\
& $\mathrm{Mg} \mathrm{ha} \mathrm{yr}^{-1}$ & -8.16 & +1.27 & -9.43 \\
25-Years old & $\mathrm{m}^{3}$ & -1.89 & +7.07 & -8.96 \\
& $\mathrm{Mg} \mathrm{ha}^{-1}$ & -2.33 & +8.7 & -11.03 \\
From 3- to 25 years old & $\mathrm{Mg} \mathrm{ha} \mathrm{yr}^{-1}$ & -1.61 & +6.04 & -7.65 \\
& $\mathrm{Mg} \mathrm{ha} \mathrm{yr}^{-1}$ & -1.04 & &
\end{tabular}

ISUM: improved stock unearthing method; $\mathrm{m}^{3}$ : Cumulative volume of eroded soil;

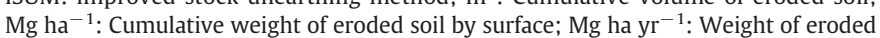
soil by surface per year. 


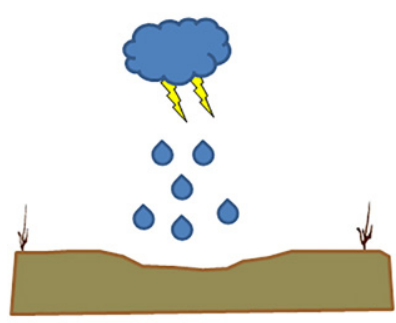

\section{Splash effect}

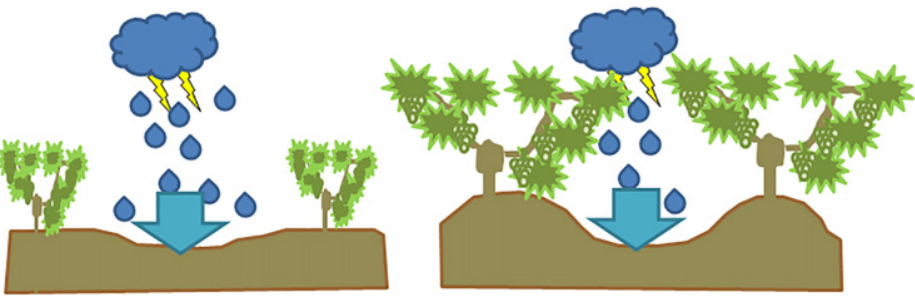

Tillage

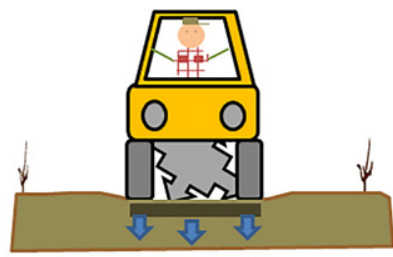

0 years

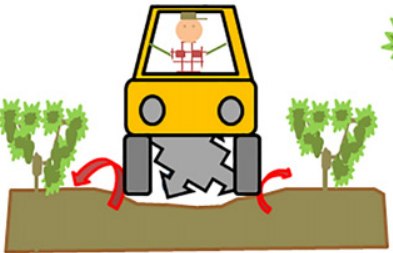

2 years

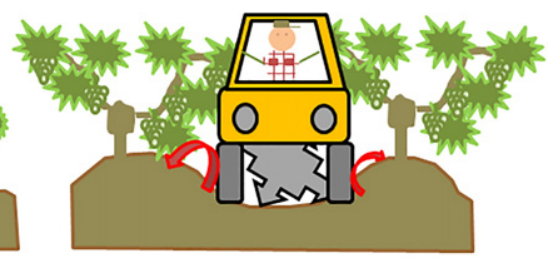

25 years

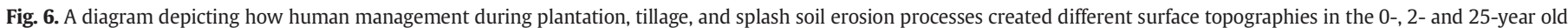
vineyards.

effect of tillage has been found to be relevant in different regions of the world including Ecuadorian Paramo (Poulenard et al., 2001), the Punjab in India (Bhatt and Khera, 2006) and the USA (Bradford and Huang, 1994). This is why there is a need for a new paradigm in soil erosion research that seeks better understanding of erosion mechanisms, factors and processes (as opposed to a single process) and their roles shaping the world's landscapes (Poeppl et al., 2017). This information should be also used in soil erosion models (Ramos and Mulligan, 2005).

The soil erosion rates were higher in the younger plots in our study due to soil disturbance from the recent plantation. The plantation works smoothed the soils, thus runoff is easily activated and very efficient in the 2 year old plots. Our research also demonstrated that the development of a ridge under the vines due to tillage reduced erosion rates at the slope and partial slope scales because the ridge reduced the connectivity of the flows. Most of the geomorphological activity was concentrated in the inter-row, with the ridges under the vines disconnecting the slope and reducing overland flow. There are other relevant processes that reduce soil losses in vineyards with time since plantation of vines; one is the increase in the vine biomass. It is important to emphasize that soil erosion is highly determined by raindrop impact and with the growth of the vines after some years, rainfall erosivity is reduced due to the soil protection they provide (Fig. 6). Herwitz (1987) showed
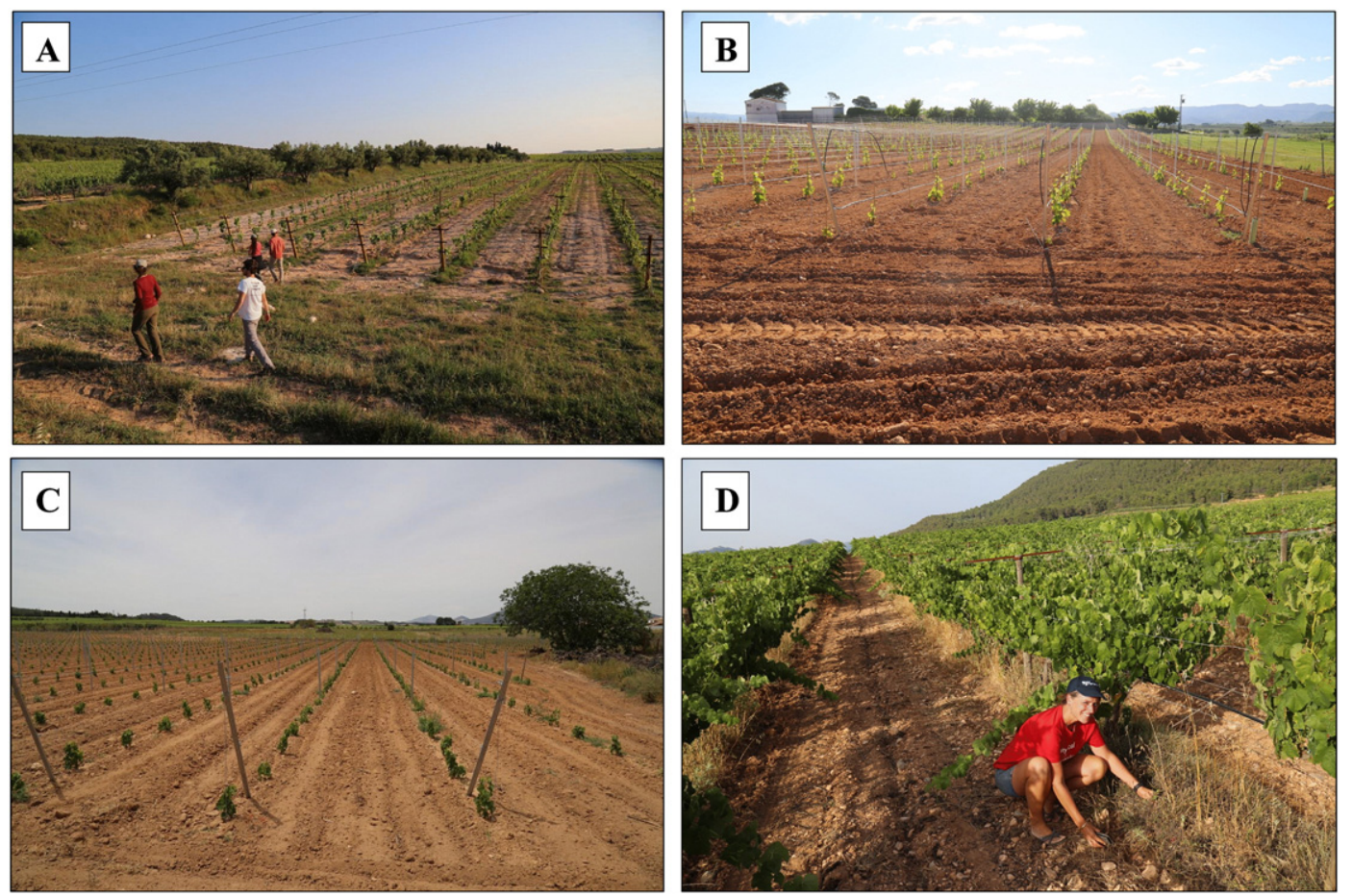

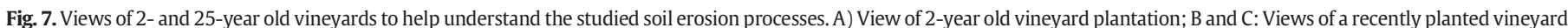

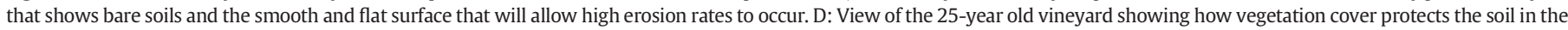

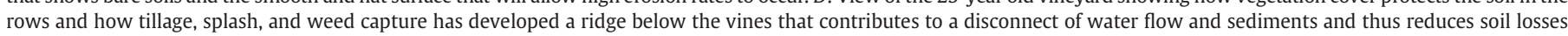
(Photographs courtesy of Prof. Saskia Keesstra, University of Wageningen). 
that raindrop impact is relevant for stemflow and throughfall, but it is also relevant for soil detachment, the development of crusts, and runoff generation (Morin and Van Winkel, 1996; Vaezi et al., 2017a).

The vine leaf cover also contributes to enhanced infiltration and reduced runoff in the vine rows, and surface runoff is reduced as a consequence of interception. The stemflow and throughfall promote lower runoff rates in the ridge where weeds germinate and plants grow due to the lack of tillage along the vine rows. The row area is covered by vegetation and soil materials are accumulated due to tillage, splash, and the fact that the vegetation growing in the row catches and holds the soil tilled or splashed into it. This is an important process that should be researched with measurements on agriculture crops, as there is currently little research available. Leuning et al. (1994) demonstrated that rainfall interception in wheat fields is relevant, and Kozak et al. (2007) showed that rainfall interception is a key process in semiarid crops. We found that soil erosion in vineyards is related to the age of the vines, and that the older vines slow down soil erosion rates due to the dis-connectivity developed by the ridges the tillage created under the row of vines.

After one year, recently planted vineyards showed higher runoff and soil erosion rates than older ones under simulated rainfall (Cerdà et al., 2017b). The impact of recent plantations on the physical properties of soil (mainly lower roughness) resulted in increased water and sediment connectivity and thus erosion. This resulted in a reduction in the ecosystems services the soils offer (Galati et al., 2016; Parras-Alcántara et al., 2016). In addition, soil plots from recently planted vineyards showed enhanced runoff rates and non-sustainable soil losses, which indicate a particular need to apply strategies to reduce soil losses during the plantation of vineyards and in the years shortly after vineyard establishment. We suggest increasing the vegetation cover immediately after the plantation with catch crops or weeds. However this will still give a window of disturbance that will result in high erosion rates. Mulches such as grass cover or straw, which were tested by Prosdocimi et al. (2016b) in the study area and also supported by the findings of other colleagues (Biddoccu et al., 2016; Kirchhoff et al., 2017; Morvan et al., 2014), would reduce erosion immediately after plantation. Other crops are successfully using straw mulch to reduce soil and water losses (Cerdà et al., 2017b) and recover the organic matter content in degraded soils, which is a proper nature-based solution to achieve sustainability (Keesstra et al., 2018). Splash can also be a key issue in the redistribution of the sediments in vineyards as the ridge under the vine rows demonstrates and the use of vegetation and mulch cover can contribute to reduced splash erosion (Fernández-Raga et al., 2017; Vaezi et al., 2017b).

Recently, other crops have received attention regarding the age of plantation as a factor in soil erosion and degradation. In China, several researchers are paying attention to the impact and influence of the age of plantation on forested soils and agricultural fields with trees. Genet et al. (2008) found that older root systems are able to reinforce hillslopes against erosion better than young root systems. Older plants allow microbial activity to form better aggregates along studied chronosequences (Cao et al., 2008; Wang et al., 2017). Li et al. (2017) also observed an increase in soil water content with age in jujube plantations of different ages (2, 6, 10 and 15-years old). There are many lines of evidence that the high erosion rates in orchards and vineyards are coming from the plantation works that are a part of land levelling. Capolongo et al. (2008) found that land-levelling is a source of high sediment yield in agricultural land in Basilicata, Italy. Lundekvam et al. (2003) also pointed out this issue in their research into the effects of soil erosion policies in Norway, where land-levelling was applied in the agricultural valleys in the southern part of the country. In vineyards, the research of Martínez-Casasnovas et al. (2009) and Ramos and Martínez-Casasnovas (2007) are the main sources of information to understand how land levelling and plantation works leave the soil bare and compacted, triggering high erosion rates. Given the background above, it is expected that the soil erosion rates measured with topographical methods such as ISUM will show high average erosion rates during the post-plantation period. Here we calculated the average soil erosion rates in the mature vineyards as $1 \mathrm{Mg} \mathrm{ha}^{-1} \mathrm{yr}^{-1}$ over a 25 year period, with much higher rates in the 2-year old vineyard (8.16 $\mathrm{Mg} \mathrm{ha}^{-1} \mathrm{yr}^{-1}$ ). Then, the widespread view that the vineyards have non-sustainable soil erosion rates should be updated. We demonstrate in this paper that the majority of the sediment yield is coming from the first few years after the plantation and as a consequence of plantation works with heavy machinery.

Measuring erosion is not an easy task and it cannot be assumed that erosion measurements are a "real truth", this really depends on the measurement technique and where and under which conditions this is applied. For example, by taking into account such a consideration, Napoli et al. (2016) also evaluated the soil loss along a transect perpendicular to the slope using a "profile meter" on $10 \%$ of the plants in the vineyard. Napoli et al. (2016) probably measured a more reliable soil loss value along the inter-row than that measured along the rows. ISUM has more detail along the rows rather than along the inter-rows. Therefore, a possible solution would be to make more than three measurements in the inter-row areas to increase the accuracy, as has been demonstrated in previous soil erosion surveys (Keesstra et al., 2016a, 2016b; Vaezi et al., 2017c).

Because ISUM uses permanent biological markers, the estimation of soil depletion and accumulation without disruption of the vineyard was possible. We point out the limitations of SUM in comparison to ISUM. ISUM increased the accuracy of erosions measurements due to the increase (from 2 to 5 ) in measurement points. The area between vinerows (inter-rows) is not flat due to the micro-topographical changes generated by the tillage practices, fauna burrowing, plant growth and overland flow and splash effect, which SUM does not survey. The general assumption that the graft union is always at the same height may in some cases be violated. Thus, by using more points, error should be reduced. The third improvement is the higher quality of the maps, which take into account the roughness generated by linear features, ponds or point topographical changes due to the consolidation of the soil or fauna burrowing. We acknowledge that the ISUM/SUM maps are ephemeral due to ploughing and the consolidation of soils after tillage, but this issue, in general, affects any mapping method and does not compromise the accuracy of ISUM more than any other method. There is an increase in the total measurement time effort of $\approx 20 \%$ compared to SUM, but most of the time in either method (SUM and ISUM) is invested in the task of finding and measuring the graft unions.

Our research confirms that erosion surveys in vineyards should pay attention to the age of the vineyards and also to the presence or absence of ridges developed by tillage as they are responsible for the disconnectivity of the system, and as a consequence reduce soil erosion rates. We propose that future research programs should quantify the erosional impact of planting new vineyards, and develop practices and policies that will promote sustainable land management. We propose a combination of geotextiles, mulches, catch crops, and the reduction of heavy machinery use always within nature-based solutions for a sustainable agriculture such as Mekonnen et al. (2017) found in Ethiopia and Sharma et al. (2017) in India under agriculture land conditions.

\section{Conclusions}

The use of a topographical method to determine soil erosion rates over 2- and 25-years in vineyards demonstrated that the older vineyards showed lower erosion rates than the recently planted vineyards. This was because soil erosion was extremely high during the plantation of the vines and in the years shortly after plantation. Soil losses in the years after plantation were not sustainable, with rates of $-8.16 \mathrm{Mg} \mathrm{ha}^{-1} \mathrm{yr}^{-1}$. The good news was that when investigating a 25-year period after plantation the mean soil erosion rate was $-1.61 \mathrm{Mg} \mathrm{ha}^{-1} \mathrm{yr}^{-1}$. And during the period from 3 to 25 years after plantation the soil erosion rate reduced to $-1.04 \mathrm{Mg} \mathrm{ha}^{-1} \mathrm{yr}^{-1}$. This 
was because tillage promoted the development of a ridge under the vines that disconnected water flow through the inter-rows, thus also reducing soil losses with time. Cover by the grape crop was also relevant due to the increase of vine cover (and weeds beneath the vines) with time. That reduced soil losses as the plants leaves intercepted the splash and deposited soil under the vines. Soil erosion control strategies should be developed and applied particularly in the immediately postplantation period, when the soil erosion rates are at their highest and most un-sustainable.

\section{Acknowledgements}

This research was funded by the European Union Seventh Framework Program (FP7/2007-2013) under grant no. 603498 (RECARE Project). We acknowledge the winery Celler del Roure and its owner Pablo Calatayud for providing access to the study area. The first author, J. Rodrigo-Comino, was issued a grant for this study under the framework of a short term scientific mission (COST-STSM-ECOST-STSMES1306-010217-081877). We also thank the Bachelor degree and PhD students: Carlos Atienza, Alberto Belenguer, Jorge García Jiménez, José Vicente Vega, Beatriz Stambuck, Jason Davis and Asmare Wubet for the time, effort and hard work during the field campaign.

\section{References}

Arnaez, J., Lasanta, T., Ruiz-Flaño, P., Ortigosa, L., 2007. Factors affecting runoff and erosion under simulated rainfall in Mediterranean vineyards. Soil Tillage Res. 93:324-334. https://doi.org/10.1016/j.still.2006.05.013.

Atucha, A., Merwin, I.A., Brown, M.G., Gardiazabal, F., Mena, F., Adriazola, C., Lehmann, J., 2013. Soil erosion, runoff and nutrient losses in an avocado (Persea americana Mill.) hillside orchard under different groundcover management systems. Plant Soil 368, 393-406.

Bhatt, R., Khera, K.L., 2006. Effect of tillage and mode of straw mulch application on soil erosion in the submontaneous tract of Punjab, India. Soil Tillage Res. 88, 107-115.

Biddoccu, M., Ferraris, S., Cavallo, E., Opsi, F., Previati, M., Canone, D., 2013. Hillslope vineyard rainfall-runoff measurements in relation to soil infiltration and water content. Procedia Environ Sci 19:351-360. https://doi.org/10.1016/j.proenv.2013.06.040.

Biddoccu, M., Ferraris, S., Opsi, F., Cavallo, E., 2016. Long-term monitoring of soil management effects on runoff and soil erosion in sloping vineyards in Alto Monferrato (North-West Italy). Soil Tillage Res. 155:176-189. https://doi.org/10.1016/ j.still.2015.07.005.

Biddoccu, M., Zecca, O., Audisio, C., Godone, F., Barmaz, A., Cavallo, E., 2017. Assessment of long-term soil erosion in a mountain vineyard, Aosta Valley (NW Italy). Land Degrad. Dev. https://doi.org/10.1002/ldr.2657.

Bogunovic, I., Bilandzija, D., Andabaka, Z., Stupic, D., Rodrigo-Comino, J., Cacic, M., Brezinscak, L., Maletic, E., Pereira, P., 2017. Soil compaction under different management practices in a Croatian vineyard. Arab. J. Geosci. 10:1-9. https://doi.org/ 10.1007/s12517-017-3105-y.

Bradford, J.M., Huang, C., 1994. Interrill soil erosion as affected by tillage and residue cover. Soil Tillage Res. 31:353-361. https://doi.org/10.1016/0167-1987(94)90041-8.

Brenot, J., Quiquerez, A., Petit, C., Garcia, J.-P., Davy, P., 2006. Soil erosion rates in Burgundian vineyards. Boll. Soc. Geol. Ital. 6, 169-173.

Brenot, J., Quiquerez, A., Petit, C., Garcia, J.-P., 2008. Erosion rates and sediment budgets in vineyards at $1-\mathrm{m}$ resolution based on stock unearthing (Burgundy, France). Geomorphology 100:345-355. https://doi.org/10.1016/j.geomorph.2008.01.005.

Brevik, E.C., Fenton, T.E., 2004. The effect of changes in bulk density on soil electrical conductivity as measured with the Geonics EM-38. Soil Horiz. 45:96-102. https:// doi.org/10.2136/sh2004.3.0096.

Cao, C., Jiang, D., Teng, X., Jiang, Y., Liang, W., Cui, Z., 2008. Soil chemical and microbiological properties along a chronosequence of Caragana microphylla Lam. plantations in the Horqin sandy land of Northeast China. Appl. Soil Ecol. 40:78-85. https://doi.org/ 10.1016/j.apsoil.2008.03.008.

Capolongo, D., Pennetta, L., Piccarreta, M., Fallacara, G., Boenzi, F., 2008. Spatial and temporal variations in soil erosion and deposition due to land-levelling in a semi-arid area of Basilicata (Southern Italy). Earth Surf. Process. Landf. 33:364-379. https:// doi.org/10.1002/esp.1560

Casalí, J., Giménez, R., De Santisteban, L., Álvarez-Mozos, J., Mena, J., Del Valle de Lersundi, J., 2009. Determination of long-term erosion rates in vineyards of Navarre (Spain) using botanical benchmarks. Catena 78:12-19. https://doi.org/10.1016/ j.catena.2009.02.015.

Cerdà, A., González-Pelayo, Ó., Giménez-Morera, A., Jordán, A., Pereira, P., Novara, A. Brevik, E.C., Prosdocimi, M., Mahmoodabadi, M., Keesstra, S., Orenes, F.G., Ritsema, C.J., 2016. Use of barley straw residues to avoid high erosion and runoff rates on persimmon plantations in eastern Spain under low frequency-high magnitude simulated rainfall events. Soil Res. 54, 154-165.

Cerdà, A., Keesstra, S.D., Rodrigo-Comino, J., Novara, A., Pereira, P., Brevik, E., GiménezMorera, A., Fernández-Raga, M., Pulido, M., di Prima, S., Jordán, A., 2017a. Runoff initiation, soil detachment and connectivity are enhanced as a consequence of vineyards plantations. J. Environ. Manag. 202:268-275. https://doi.org/10.1016/ j.jenvman.2017.07.036

Cerdà, A., Rodrigo-Comino, J., Giménez-Morera, A., Keesstra, S.D., 2017b. An economic, perception and biophysical approach to the use of oat straw as mulch in Mediterranean rainfed agriculture land. Ecol. Eng. 108, 162-171.

Fernández-Raga, M., Palencia, C., Keesstra, S., Jordán, A., Fraile, R., Angulo-Martínez, M. Cerdà, A., 2017. Splash erosion: a review with unanswered questions. Earth-Sci. Rev. 171:463-477. https://doi.org/10.1016/j.earscirev.2017.06.009.

Galati, A., Crescimanno, M., Gristina, L., Keesstra, S., Novara, A., 2016. Actual provision as an alternative criterion to improve the efficiency of payments for ecosystem services for C sequestration in semiarid vineyards. Agric. Syst. 144:58-64. https://doi.org/ 10.1016/j.agsy.2016.02.004.

García-Díaz, A., Bienes, R., Sastre, B., Novara, A., Gristina, L., Cerdà, A., 2017. Nitrogen losses in vineyards under different types of soil groundcover. A field runoff simulator approach in central Spain. Agric. Ecosyst. Environ. 236:256-267. https://doi.org/ 10.1016/j.agee.2016.12.013.

García-Ruiz, J.M., Beguería, S., Lana-Renault, N., Nadal-Romero, E., Cerdà, A., 2017. Ongoing and emerging questions in water erosion studies. Land Degrad. Dev. 28:5-21. https://doi.org/10.1002/ldr.2641.

Genet, M., Kokutse, N., Stokes, A., Fourcaud, T., Cai, X., Ji, J., Mickovski, S., 2008. Root reinforcement in plantations of Cryptomeria japonica D. Don: effect of tree age and stand structure on slope stability. For. Ecol. Manag. 256:1517-1526. https://oi.org/ 10.1016/j.foreco.2008.05.050.

Govers, G., Quine, T.A., Desmet, P.J.J., Walling, D.E., 1996. The relative contribution of soil tillage and overland flow erosion to soil redistribution on agricultural land. Earth Surf Process. Landf. 21:929-946. https://doi.org/10.1002/(SICI)1096-9837(199610)21: 10<929::AID-ESP631>3.0.CO;2-C.

Herwitz, S.R., 1987. Raindrop impact and water flow on the vegetative surfaces of trees and the effects on stemflow and throughfall generation. Earth Surf. Process. Landf. 12:425-432. https://doi.org/10.1002/esp.3290120408.

IUSS Working Group WRB, 2014. World Reference Base for Soil Resources 2014, World Soil Resources Report. FAO, Rome.

Jianjun, W., Quansheng, L., Lijiao, Y., 2017. Effect of intercropping on soil erosion in young citrus plantation - a simulation study. Chin. J. Appl. Ecol. 8, 143-146.

Keesstra, S.D., Bouma, J., Wallinga, J., Tittonell, P., Smith, P., Cerdà, A., Montanarella, L., Quinton, J.N., Pachepsky, Y., van der Putten, W.H., Bardgett, R.D., Moolenaar, S., Mol, G., Jansen, B., Fresco, L.O., 2016a. The significance of soils and soil science towards realization of the United Nations sustainable development goals. Soil 2 (111-128): 2016. https://doi.org/10.5194/soil-2-111-2016.

Keesstra, S., Pereira, P., Novara, A., Brevik, E.C., Azorin-Molina, C., Parras-Alcántara, L., Jordán, A., Cerdà, A., 2016b. Effects of soil management techniques on soil water erosion in apricot orchards. Sci. Total Environ. 551-552:357-366. https://doi.org/ 10.1016/j.scitotenv.2016.01.182.

Keesstra, S., Nunes, J., Novara, A., Finger, D., Avelar, D., Kalantari, Z., Cerdà, A., 2018. The superior effect of nature based solutions in land management for enhancing ecosystem services. Sci. Total Environ. 610-611:997-1009. https://doi.org/10.1016/ j.scitotenv.2017.08.077.

Kimoto, A., Nearing, M.A., Shipitalo, M.J., Polyakov, V.O., 2006. Multi-year tracking of sediment sources in a small agricultural watershed using rare earth elements. Earth Surf Process. Landf. 31:1763-1774. https://doi.org/10.1002/esp.1355.

Kirchhoff, M., Rodrigo-Comino, J., Seeger, M., Ries, J.B., 2017. Soil erosion in sloping vineyards under conventional and organic land use managements (SaarMosel Valley, Germany). Cuad. Investig. Geográfica 43. https://doi.org/10.18172/ cig.3161.

Köpppen, W., Geiger, R., 1954. Klima der Erde. Justus Perthes. ed (Darmstadt, Germany).

Kozak, J.A., Ahuja, L.R., Green, T.R., Ma, L., 2007. Modelling crop canopy and residue rainfall interception effects on soil hydrological components for semi-arid agriculture. Hydrol. Process. 21:229-241. https://doi.org/10.1002/hyp.6235.

Lasanta, T., 1985. Aportación al estudio de la erosión hídrica en campos cultivados de la Rioja, Ciencias de la Tierra. Instituto de Estudios Riojanos, Logroño (Spain).

Le Gall, M., Evrard, O., Dapoigny, A., Tiecher, T., Zafar, M., Minella, J.P.G., Laceby, J.P., Ayrault, S., 2017. Tracing sediment sources in a subtropical agricultural catchment of Southern Brazil cultivated with conventional and conservation farming practices. Land Degrad. Dev. 28:1426-1436. https://doi.org/10.1002/ldr.2662.

Leuning, R., Condon, A.G., Dunin, F.X., Zegelin, S., Denmead, O.T., 1994. Rainfall interception and evaporation from soil below a wheat canopy. Agric. For. Meteorol. 67: 221-238. https://doi.org/10.1016/0168-1923(94)90004-3.

Li, L., Gao, X., Wu, P., Zhao, X., Li, H., Ling, Q., Sun, W., 2017. Soil water content and root patterns in a rain-fed jujube plantation across stand ages on the loess plateau of China. Land Degrad. Dev. 28:207-216. https://doi.org/10.1002/ldr.2540.

Lundekvam, H.E., Romstad, E., Øygarden, L., 2003. Agricultural policies in Norway and effects on soil erosion. Environ. Sci. 6:57-67 Policy, Socio-economic Factors in Soil Erosion and Conservation. https://doi.org/10.1016/S1462-9011(02)00118-1.

Martinez-Casasnovas, J.A., Ramos, M.C., Ribes-Dasi, M., 2002. Soil erosion caused by extreme rainfall events: mapping and quantification in agricultural plots from very detailed digital elevation models. Geoderma 105:125-140. https://doi.org/10.1016/ S0016-7061(01)00096-9.

Martínez-Casasnovas, J.A., Ramos, M.C., García-Hernández, D., 2009. Effects of land-use changes in vegetation cover and sidewall erosion in a gully head of the Penedès region (northeast Spain). Earth Surf. Process. Landf. 34:1927-1937. https://doi.org/ 10.1002/esp.1870.

Masselink, R.J., Heckmann, T., Temme, A.J., Anders, N.S., Gooren, H., Keesstra, S.D., 2017a. A network theory approach for a better understanding of overland flow connectivity. Hydrol. Process. 31 (1), 207-220.

Masselink, R., Temme, A.J.A.M., Giménez, R., Casalí, J., Keesstra, S.D., 2017b. Assessing hillslope-channel connectivity in an agricultural catchment using rare-earth oxide 
tracers and random forests models. Cuad. Investig. Geográfica 43:19-39. https:// doi.org/10.18172/cig.3169.

Mekonnen, M., Keesstra, S.D., Baartman, J.E., Stroosnijder, L., Maroulis, J., 2017. Reducing sediment connectivity through manmade and natural sediment sinks in the Minizr Catchment, Northwest Ethiopia. Land Degrad. Dev. 28 (2), 708-717.

Morin, J., Van Winkel, J., 1996. The effect of raindrop impact and sheet erosion on infiltration rate and crust formation. Soil Sci. Soc. Am. J. 60:1223-1227. https://doi.org/ 10.2136/sssaj1996.03615995006000040038x.

Morvan, X., Naisse, C., Malam Issa, O., Desprats, J.F., Combaud, A., Cerdan, O., 2014. Effect of ground-cover type on surface runoff and subsequent soil erosion in champagne vineyards in France. Soil Use Manag. 30:372-381. https://doi.org/10.1111/ sum.12129.

Napoli, M., Cecchi, S., Orlandini, S., Mugnai, G., Zanchi, C.A., 2016. Simulation of fieldmeasured soil loss in Mediterranean hilly areas (Chianti, Italy) with RUSLE. Catena 145:246-256. https://doi.org/10.1016/j.catena.2016.06.018.

Napoli, M., Marta, A.D., Zanchi, C.A., Orlandini, S., 2017a. Assessment of soil and nutrient losses by runoff under different soil management practices in an Italian hilly vineyard. Soil Tillage Res. 168:71-80. https://doi.org/10.1016/j.still.2016.12.011.

Napoli, M., Massetti, L., Orlandini, S., 2017b. Hydrological response to land use and climate changes in a rural hilly basin in Italy. Catena 157:1-11. https://doi.org/10.1016/ j.catena.2017.05.002.

Novara, A., Gristina, L., Saladino, S.S, Santoro, A. Cerdà, A., 2011. Soil erosion assessment on tillage and alternative soil managements in a Sicilian vineyard. Soil Tillage Res. 117:140-147. https://doi.org/10.1016/j.still.2011.09.007.

Novara, A., Gristina, L., Guaitoli, F., Santoro, A., Cerdà, A., 2013. Managing soil nitrate with cover crops and buffer strips in Sicilian vineyards. Solid Earth 4:255-262. https://doi.org/10.5194/se-4-255-2013.

Paroissien, J.-B., Lagacherie, P., Le Bissonnais, Y., 2010. A regional-scale study of multidecennial erosion of vineyard fields using vine-stock unearthing-burying measurements. Catena 82:159-168. https://doi.org/10.1016/j.catena.2010.06.002.

Parras-Alcántara, L., Lozano-García, B., Keesstra, S., Cerdà, A., Brevik, E.C., 2016. Long-term effects of soil management on ecosystem services and soil loss estimation in olive grove top soils. Sci. Total Environ. 571:498-506. https://doi.org/10.1016/ j.scitotenv.2016.07.016.

Peel, M.C., Finlayson, B.L., McMahon, T.A., 2007. Updated world map of the Köppen-Geiger climate classification. Hydrol. Earth Syst. Sci. 11:1633-1644. https://doi.org/10.5194/ hess-11-1633-2007.

Poeppl, R.E., Keesstra, S.D., Maroulis, J., 2017. A conceptual connectivity framework for understanding geomorphic change in human-impacted fluvial systems. Geomorphology 277:237-250. https://doi.org/10.1016/j.geomorph.2016.07.033.

Poulenard, J., Podwojewski, P., Janeau, J.-L., Collinet, J., 2001. Runoff and soil erosion under rainfall simulation of Andisols from the Ecuadorian Páramo: effect of tillage and burning. Catena 45:185-207. https://doi.org/10.1016/S0341-8162(01)00148-5.

Prosdocimi, M., Cerdà, A., Tarolli, P., 2016a. Soil water erosion on Mediterranean vineyards: a review. Catena 141:1-21. https://doi.org/10.1016/j.catena.2016.02.010.

Prosdocimi, M., Jordán, A., Tarolli, P., Keesstra, S., Novara, A., Cerdà, A., 2016b. The immediate effectiveness of barley straw mulch in reducing soil erodibility and surface runoff generation in Mediterranean vineyards. Sci. Total Environ. 547:323-330. https:// doi.org/10.1016/j.scitotenv.2015.12.076.

Ramos, M.C. Martínez-Casasnovas, J.A., 2007. Soil loss and soil water content affected by land levelling in Penedès vineyards, NE Spain. Catena 71:210-217. https://doi.org/ 10.1016/j.catena.2007.03.001

Ramos, M.C., Martínez-Casasnovas, J.A., 2009. Impacts of annual precipitation extremes on soil and nutrient losses in vineyards of NE Spain. Hydrol. Process. 23:224-235. https://doi.org/10.1002/hyp.7130.

Ramos, M.C., Mulligan, M., 2005. Spatial modelling of the impact of climate variability on the annual soil moisture regime in a mechanized Mediterranean vineyard. J. Hydrol. 306:287-301. https://doi.org/10.1016/j.jhydrol.2004.09.013.

Ramos, M.C., Porta, J., 1997. Analysis of design criteria for vineyard terraces in the Mediterranean area of North East Spain. Soil Technol. 10:155-166. https://doi.org/ 10.1016/S0933-3630(96)00006-2.

Reubens, B., Poesen, J., Danjon, F., Geudens, G., Muys, B., 2007. The role of fine and coarse roots in shallow slope stability and soil erosion control with a focus on root system architecture: a review. Trees 21:385-402. https://doi.org/10.1007/s00468-007-0132-4.
Richter, G., 1979. Bodenerosion in Rebanlagen des Moselgebietes. Ergebnisse quantitativer Untersuchungen 1974-1977. Universität Trier. ed. Forschungsstelle Bodenerosion d. Univ, Trier, Trier.

Rodrigo-Comino, J., Brings, C., Lassu, T., Iserloh, T., Senciales, J., Martínez Murillo, J., Ruiz Sinoga, J., Seeger, M., Ries, J., 2015. Rainfall and human activity impacts on soil losses and rill erosion in vineyards (Ruwer Valley, Germany). Solid Earth 6:823-837. https://doi.org/10.5194/se-6-823-2015.

Rodrigo-Comino, J. Iserloh, T. Lassu, T., Cerdà, A Keestra, S.D., Prosdocimi, M., Brings, C, Marzen, M., Ramos, M.C., Senciales, J.M., Ruiz Sinoga, J.D., Seeger, M., Ries, J.B., 2016a. Quantitative comparison of initial soil erosion processes and runoff generation in Spanish and German vineyards. Sci. Total Environ. 565:1165-1174. https://doi.org/ 10.1016/j.scitotenv.2016.05.163.

Rodrigo-Comino, J., Quiquerez, A., Follain, S., Raclot, D., Le Bissonnais, Y., Casalí, J., Giménez, R., Cerdà, A., Keesstra, S.D., Brevik, E.C., Pereira, P., Senciales, J.M., Seeger, M., Ruiz Sinoga, J.D., Ries, J.B., 2016b. Soil erosion in sloping vineyards assessed by using botanical indicators and sediment collectors in the Ruwer-Mosel valley. Agric. Ecosyst. Environ. 233:158-170. https://doi.org/10.1016/j.agee.2016.09.009.

Rodrigo-Comino, J., Senciales González, J.M., Ramos, M.C., Martínez-Casasnovas, J.A., Lasanta Martínez, T., Brevik, E.C., Ries, J.B., Ruiz-Sinoga, J.D., 2017a. Understanding soil erosion processes in Mediterranean sloping vineyards (Montes de Málaga, Spain). Geoderma 296:47-59. https://doi.org/10.1016/j.geoderma.2017.02.021.

Rodrigo-Comino, Brings, C., Iserloh, T., Casper, M.C., González, Senciales, Seeger, M. Brevik, E.C., Ruiz-Sinoga, J.D., Ries, J.B., 2017b. Temporal changes in soil water erosion on sloping vineyards in the Ruwer-Mosel Valley. The impact of age and plantation works in young and old vines. J. Hydrol. Hydromech. 65 In press. https://doi.org/ 10.1515/johh-2017-0022.

Salome, C., Coll, P., Lardo, E., Villenave, C., Blanchart, E., Hinsinger, P., Marsden, C., Le Cadre, E., 2014. Relevance of use-invariant soil properties to assess soil quality of vulnerable ecosystems: the case of Mediterranean vineyards. Ecol. Indic. 43:83-93. https:// doi.org/10.1016/j.ecolind.2014.02.016.

Serpa, D., Nunes, J.P., Keizer, J.J., Abrantes, N., 2017. Impacts of climate and land use changes on the water quality of a small Mediterranean catchment with intensive viticulture. Environ. Pollut. https://doi.org/10.1016/j.envpol.2017.02.026 Barking Essex 1987 In press.

Sharma, N.K., Singh, R.J., Mandal, D., Kumar, A., Alam, N.M., Keesstra, S., 2017. Increasing farmer's income and reducing soil erosion using intercropping in rainfed maize-wheat rotation of Himalaya, India. Agric. Ecosyst. Environ. 247:43-53. https://doi.org/10.1016/j.agee.2017.06.026.

Taguas, E.V., Ayuso, J.L., Pérez, R., Giráldez, J.V., Gómez, J.A., 2013. Intra and inter-annual variability of runoff and sediment yield of an olive micro-catchment with soil protection by natural ground cover in southern Spain. Geoderma 206:49-62. https://doi.org/10.1016/j.geoderma.2013.04.011.

Taguas, E.V., Guzmán, E Guzmán, G. Vanwalleghem, T. Gómez J.A. 2015. Characteristics and importance of rill and gully erosion: a case study in a small catchment of a marginal olive grove. Cuad. Investig. Geográfica 41:107-126. https://doi.org/10.18172/ cig.2644.

Tarolli, P., Sofia, G., Calligaro, S., Prosdocimi, M., Preti, F., Dalla Fontana, G., 2015. Vineyards in terraced landscapes: new opportunities from Lidar data. Land Degrad. Dev. 26: 92-102. https://doi.org/10.1002/ldr.2311.

Vaezi, A.R., Abbasi, M., Bussi, G., Keesstra, S., 2017a. Modeling sediment yield in semiarid pasture micro-catchments, NW Iran. Land Degrad. Dev. 28:1274-1286. https://doi.org/10.1002/ldr.2526.

Vaezi, A.R., Ahmadi, M., Cerdà, A., 2017b. Contribution of raindrop impact to the change of soil physical properties and water erosion under semi-arid rainfalls. Sci. Total Environ. 583:382-392. https://doi.org/10.1016/j.scitotenv.2017.01.078.

Vaezi, A.R., Abbasi, M., Keesstra, S., Cerdà, A., 2017c. Assessment of soil particle erodibility and sediment trapping using check dams in small semi-arid catchments. Catena 157: 227-240. https://doi.org/10.1016/j.catena.2017.05.021.

Wahba, G., 1990. Spline Models for Observational Data. Philadelphia. Society for Industrial and Applied Mathematics, Philadelphia, USA.

Wang, S., Li, T., Zheng, Z., 2017. Distribution of microbial biomass and activity within soil aggregates as affected by tea plantation age. Catena 153:1-8. https://doi.org/10.1016/ j.catena.2017.01.029. 